\title{
Characterisation of Staphylococcus aureus isolated from cases of bovine subclinical mastitis in two Uruguayan dairy farms
}

\author{
Caracterización de Staphylococcus aureus aislados a partir de casos de mastitis \\ subclínicas en dos tambos de Uruguay
}

\author{
R de los Santos ${ }^{\mathrm{a}}$, M Fernández ${ }^{\mathrm{b}}$, S Carro ${ }^{\mathrm{a}}$, P Zunino ${ }^{\mathrm{b} *}$ \\ ${ }^{a}$ Milk Science and Technology Department, Faculty of Veterinary, Universidad dela República, Montevideo, Uruguay. \\ ${ }^{\mathrm{b}}$ Department of Microbiology, Instituto de Investigaciones Biológicas Clemente Estable, Montevideo, Uruguay.
}

\begin{abstract}
SUMMARY
The aim of this work was to identify and to characterise Staphylococcus aureus isolates associated with subclinical mastitis obtained from milk of lactating cows showing a California Mastitis Test (CMT) score result of traces, 1, 2 or 3. Coagulase, hemolysis, presence of capsule, slime formation, biofilm production, autoaggregation, hemagglutination and antibiotic susceptibility were assessed to evaluate $S$. aureus virulence factors expression potentially associated to bovine subclinical mastitis isolates. Prevalence of subclinical mastitis along the study was low and did not correlate with months or climatic variables. Most of $S$. aureus (20) were isolated from milk samples showing a CMT score result of 1. Formation of capsule, slime, biofilms and the occurrence of bacteria aggregation in all the tested isolates converged in the bacterial ability of adherence and persistence in the mammary gland and probably contribute to the further chronicity of the infection and even the colonization of dairy installations. Resistance against a set of commonly used antibiotics was low. The evaluation of virulence factors of $S$. aureus isolates in the context of subclinical mastitis in dairy farms may be useful to develop precise actions and treatments to control mastitis and to improve animal health and milk production in dairy bovine herds.
\end{abstract}

Key words: bovine subclinical mastitis, Staphylococcus aureus, virulence factors, Uruguay.

\section{RESUMEN}

El objetivo de este trabajo fue evaluar la prevalencia y evolución de mastitis bovina subclínica (MBS) a lo largo de un año en dos tambos comerciales localizados en un área de producción lechera (Sur) de Uruguay e identificar y caracterizar cepas de Staphylococcus aureus aisladas de la leche de vacas con resultados de trazas, 1, 2 o 3 correspondientes a la escala del California Mastitis Test (CMT). Producción de coagulasa, presencia de cápsula, producción de limo, formación de biofilms, autoagregación, hemaglutinación y sensibilidad a diferentes antibióticos fueron evaluadas en el caso de las cepas de $S$. aureus aisladas. La incidencia de MBS a lo largo del estudio fue baja y no se correlacionó con variables climáticas. El número de aislamientos de $S$. aureus de las muestras de leche fue bajo en comparación con estudios previos y la mayoría de ellos se obtuvo de muestras que presentaban un resultado de CMT de 1. La formación de cápsula, limo y biofilms así como la ocurrencia de autoagregación en todas las cepas confluyen en la habilidad bacteriana para adherirse y persistir en la glándula contribuyendo a la cronicidad de la infección y a la adhesión a superficies inertes. La resistencia bacteriana frente a distintos antibióticos fue baja. La evaluación de la expresión de factores de virulencia de $S$. aureus en el contexto de mastitis subclínica en tambos puede ser de utilidad para desarrollar acciones precisas y tratamientos para el control de mastitis y la promoción de la salud animal y la producción de leche.

Palabras clave: mastitis bovina subclinica, Staphylococcus aureus, factores de virulencia, Uruguay.

\section{INTRODUCTION}

Staphylococcus aureus is a natural inhabitant of human and animal skin and mucosal epithelia. It is extremely versatile, it causes a broad range of diseases and it is the most common etiologic agent of bovine contagious mastitis (Kerro Dego et al 2002), which is still the most costly disease for dairy farmers worldwide (Cressier and

Accepted: 03.10.2013.

* Avda. Italia 3318, C.P. 11.600, Montevideo, Uruguay; pablo@iibce. edu.uy
Bissonnette 2011). This bacterium expresses a high number of virulence factors that vary among strains, potentially associated with the establishment and pathogenesis of intrammamary inflammation (IMI).

Staphylococcal mastitis causes clinical and subclinical IMI which may persist along successive lactation periods. $S$. aureus has the ability to acquire resistance to antimicrobial drugs, making treatment difficult and often unsuccessful (Sommerhauser et al 2003). Prevalence of antimicrobial-resistant strains isolated from mastitic ruminants is a serious problem worldwide (Kumar et al 2011).

The importance of assessing the presence and combination of virulence factors associated to the mammary 
gland infection has been recently emphasised by different authors and support the idea that the development of subclinical mastitis could be related to strain-specific pathogenic attributes (Zecconi et al 2006).

The aim of this study was to identify and characterise $S$. aureus isolates associated with subclinical mastitis in two commercial dairy herds located in the dairy production geographic area of Uruguay (South), obtained from milk of affected cows. Expression of virulence factors by the different isolates and antimicrobial susceptibility patterns were assessed.

\section{MATERIAL AND METHODS}

\section{COWS}

The study was conducted between May 2008 to April 2009 in two dairy farms of Southern Uruguay, located close to the cities of Pando and Libertad. Somatic cells count recorded in bulk milk were lower than 200,000 cells $\mathrm{mL}^{-1}$, despite a reasonably good udder health management. Cows, mostly grazed on pasture, were milked twice a day. Both herds had an annual record of about $1,500 \mathrm{~L}$ of milk per day.

\section{MILK SAMPLING}

All milking cows were tested monthly using the California Mastitis Test (CMT), a simple and widely used tool to detect subclinical mastitis (Persson et al 2011), which yields an ordinal variable related with the increase of milk somatic cell counts (SCC) as a consequence of udder inflammation (Feitosa Brito et al 1997). Quarters that showed CMT detectable values (traces, 1, 2 or 3, according to the intensity of the reaction) were sampled and the milk was submitted for bacterial culture. Milk samples were collected according to the National Mastitis Council guidelines (National Mastitis Council 1981).

\section{BACTERIAL ISOLATION}

Milk samples were streaked onto 5\% sheep Blood Agar $^{1,2}$ (BA) and Baird Parker Agar ${ }^{2}$ (BPA) plates and incubated aerobically at $37^{\circ} \mathrm{C}$ for 24-48 h. Staphylococci were identified on the basis of Gram staining and cultural characteristics such as pigment production, haemolysis and the following biochemical reactions: catalase activity, tube coagulase test (TC), mannitol fermentation on Mannitol-Salt Agar ${ }^{1}$, deoxyribonuclease ${ }^{1}$ (DNase) test and Voges Proskauer (VP) test using VP broth ${ }^{1}$ (Roberson et al 1992, Boerlin et al 2003). S. aureus reference

\footnotetext{
1 Triptic Soy Broth (TSB), Triptic Soy Agar (TSA), Baird Parker media, Mannitol Salt Agar, DNAse media, and VP Broth from HIMEDIA, India.

2 Sheep Blood supplied from Biokey SRL, Uruguay.
}

strains were ATCC 29213 (Boerlin et al 2003), ATCC 25923 (Kateete et al 2010) and ATCC 6538 (O’Reilly et al 2000). Escherichia coli (Delucchi et al 2008) and Moraxella bovoculi (Marrs et al 1985) were also used as controls for different tests of this study.

\section{COAGULASE TEST}

Coagulase activity was determined in tubes (tube coagulase test, TC) as described by Quinn et al (2004) and examined after 4 and $24 \mathrm{~h}$.

\section{DNASE TEST}

This test was carried out by using commercially available DNase agar. Spot inoculation was done on the DNase agar plates and incubated at $37^{\circ} \mathrm{C}$ for 1 day. After incubation, clearing around the bacterial growth was evaluated as positive.

\section{CAPSULE TEST}

The presence of bacterial capsule was determined following the microscopic method described by Türkyilmaz and Kaya (2006).

\section{SLIME FORMATION}

The Congo Red Agar (CRA) method developed by Freeman was used in this assay (Türkyilmaz and Kaya 2006). Isolates producing black colonies were regarded as slime-positive. Those showing pink colonies were considered as slime-negative isolates.

\section{BIOFILM FORMATION}

Isolates were incubated on TSA blood agar plates for $18 \mathrm{~h}$ at $37^{\circ} \mathrm{C}$ under aerobic conditions. Fresh cultures were inoculated in $5 \mathrm{~mL}$ of TSB glucose $(0.25 \%)$ and then incubated at $37^{\circ} \mathrm{C}$ for $24 \mathrm{~h}$ under the same conditions. Biofilm formation was assessed by the microplate method (MP) proposed by Pfaller et al (1988) using 96 wells tissue culture plates. The plates were read using an automated plate reader (Varioscan Flash 4.00.51) at 600 nm. Sterile TSB was used as a negative control. All the experiments were performed using four replicates. Biofilm production was tested following the criteria proposed by Mathur et al (2006).

\section{HEMOLYSIS}

Hemolysis was evaluated on TSA plates supplemented with $10 \%$ sterile sheep blood. The plates were incubated for $24 \mathrm{~h}$ at $37^{\circ} \mathrm{C}$, and then overnight at $4{ }^{\circ} \mathrm{C}$. Results were considered positive when a clear zone of complete hemolysis was detected around the colonies. 


\section{HEMAGGLUTINATION}

The hemagglutination assay was performed according to the method described by Rupp and Archer (1992) with modifications. Bacterial concentrations were adjusted using a McFarland standard of 0.5 which correlated approximately with $10^{8}$ bacteria per mL. Hemagglutination assays were carried out in 96-well (U-shaped) microtiter plates (Costar, Cambridge, Mass.). The plates were sealed with laboratory film and shaken to ensure even mixing of the bacteria and erythrocytes, and then incubated at $4{ }^{\circ} \mathrm{C}$ for $2 \mathrm{~h}$. Hemagglutination was recorded as positive when erythrocyte clumps were seen. Negative and positive controls were included in the assay.

\section{AUTOAGGREGATION}

Isolates were incubated on TSA blood agar plates for $18 \mathrm{~h}$ at $37^{\circ} \mathrm{C}$ under aerobic conditions. Fresh cultures were inoculated in $5 \mathrm{~mL}$ of TSB glucose $(0.25 \%)$ and then incubated at $37^{\circ} \mathrm{C}$ for $24 \mathrm{~h}$ at the same conditions. Aliquots of $5 \mu \mathrm{L}$ of the suspensions were transferred to $5 \mathrm{~mL}$ of TSB glucose which were incubated $48 \mathrm{~h}$ at the same conditions. Then, the cultures were incubated $24 \mathrm{~h}$ at $4^{\circ} \mathrm{C}$.

$200 \mu \mathrm{L}$ were extracted from the surface of each tube of culture and transferred to a 96-well (U-shaped) microtiter plate (Costar, Cambridge, Mass.). Initial Optical Density (OD) was read at $600 \mathrm{~nm}$. After this, tubes were vortexed during $30 \mathrm{sec}$ and $200 \mu \mathrm{L}$ of the cultures were transferred to a 96-well (U-shaped) microtiter plate. Final OD was read at $600 \mathrm{~nm}$. Autoaggregation percentage was calculated as: $A=\left(1-\mathrm{OD}_{\mathrm{f}} / \mathrm{OD}_{\mathrm{i}}\right) \times 100$, where $\mathrm{A}$ : Autoaggregation percentage; $\mathrm{OD}_{\mathrm{f}}$ : Final Optical Density, and $\mathrm{OD}_{\mathrm{i}}$ : Initial Optical Density.

\section{ANTIBIOTIC SUSCEPTIBILITY PATTERNS}

The Kirby-Bauer disk diffusion method (Bauer et al 1966) was used to determine resistance of $S$. $a u$ reus to Trimethoprim-Sulfametoxazole, Gentamicine, Neomycin, Penicillin, Nafcillin, Clindamycin and Ciprofloxacin. Zones of inhibition were recorded at 24 and 48 $\mathrm{h}$ and the isolates were considered susceptible, intermediately resistant, or resistant to each antibiotic according to the National Committee for Clinical Laboratory Standards (NCCLS 1997, Gandara et al 2006).

\section{STATISTICAL ANALYSIS}

In order to identify $S$. aureus isolates, a Cluster analysis using de Ochiai index simultaneously to strains and to variables (coagulase, hemolysis, VP, mannitol fermentation, DNAse, BPA) was performed. To compare biofilm production and autoaggregation (as percentage) an Exploratory Data Analysis was performed followed by
Kruskall-Wallis test between strains, and Mann-Whitney for strain classification. These procedures were followed by modified Bray-Curtis association index to find strains with similar behaviour for these two variables. All those procedures were performed by using PAST software (Hammer et al 2001); $\mathrm{P}$ values $<0.05$ were considered significant.

\section{RESULTS AND DISCUSSION}

\section{PREVALENCE OF SUBCLINICAL MASTITIS}

Considering the total cow populations of both dairy farms, the percentage of animals that showed a detectable CMT category was 8 and 19\% in the cases of Libertad and Pando, respectively. Distribution along the year did not show a defined pattern and was neither related to climatic variables like temperature, rain or humidity (data not shown). The subclinical mastitis prevalence recorded by CMT was higher in one of the farms (Pando) compared to the other located close to Libertad. This could be related to hygiene practices that were poorer in the Pando farm compared to the other one in Libertad. However, prevalence results could be considered acceptable compared to previous studies (Gianneechini et al 2002, Plozza et al 2011).

Most of the $S$. aureus isolates corresponded to milk samples that showed a Grade 1 CMT result (16 out of 20) while the remaining four were isolated from milk samples that corresponded to Grade 2 (1), Grade 3 (1) and traces (2) CMT categories. The vast majority of the identified $S$. aureus corresponded to milk samples that showed a Grade 1 CMT category (16 out of 20, 80\%). This indicated that $S$. aureus was predominantly isolated from animals that suffered a mild udder inflammation, result that may be taken into account for control strategies.

\section{BACTERIAL IDENTIFICATION}

A total of 508 milk samples showed a CMT detectable result and 63 isolates were characterised as Gram positive cocci and positive to catalase production. 20 of these isolates showed coagulase activity and developed a firm clot in the coagulase test tube (TC) at 4 hours and at $24 \mathrm{~h}$ the clot was seen in 22 isolates. Of these 22, 20 showed a consistent color change according to VP test positive reaction and were considered $S$. aureus. These 20 isolates showed hemolysis, DNAse activity and grew well on MSA; 19 of them were able to ferment mannitol, which was evidenced by a color change in the MSA plates around the colonies. All strains grew on BP plates showing a characteristic morphology and dimensions but nevertheless only 12 showed a halo of lipolysis. The two remaining isolates were identified as coagulase positive Staphylococcus other than S. aureus. 3 out of the 41 isolates of Gram positive cocci without catalase activity did not evidence coagulase activity but showed a positive 
oxidase test. These isolates belonged to the Micrococcus genus while the rest (38) were considered coagulase-negative staphylococci (CNS).

Isolates showed a positive coagulase-test result after $4 \mathrm{~h}$ of incubation. Isolate 20080849 was the only one that did not acidified MSA plates.

Identification of bacterial pathogens still relies mainly on phenotypic criteria due to costs and simplicity of the methods. Among coagulase-positive staphylococci, S. aureus is almost the only one with hemolytic activity that is regularly found in milk samples (Roberson et al 1992, Larsen et al 2002). Therefore, a combination of hemolysis and coagulase activities seems to represent an optimal criterion for the identification of $S$. aureus in cultures from milk samples (Boerlin et al 2003).

\section{PRESENCE OF CAPSULE, SLIME PRODUCTION AND HEMAGGLUTINATION}

All S. aureus isolates formed capsule and produced slime on CRA. Only 7 strains (excluding ATCC 6835 and 25923 strains used as positive controls) were able to agglutinate ovine red blood cells. Expression of capsule by $S$. aureus associated to IMI has been clearly demonstrated but this is not a constant (Buzzola et al 2007). In this study, we must consider that milk samples belonged to animals with subclinical mastitis. The presence of capsule enables to resist and evade successfully the first defense line of the host, even triggering different degrees of inflammation as seen in the CMT tests.

\section{BIOFILM FORMATION}

The S. aureus isolates were classified in high, moderate and weak biofilm producers, based on OD540 results. One of them was a high biofilm producer $\left(\mathrm{OD}_{540}\right.$ 1,24 ; lower quartile value $\mathrm{OD}_{540} 1,05$; higher quartile value $\left.\mathrm{OD}_{540} 1,32\right)$, other 10 were moderate biofilm producers (median value $\mathrm{OD}_{540} 0,42$; lower quartile value $\mathrm{OD}_{540} 0,33$; higher quartile value $\mathrm{OD}_{540} 0,53$ ) while the remaining 9 isolates produced weak biofilms (median value $\mathrm{OD}_{540} 0,21$; lower quartile value $\mathrm{OD}_{540} 0,17$; higher quartile value $\mathrm{OD}_{540} 0,25$ ) (figure 1 , panel $\mathrm{A}$ ).

During IMI, bacterial clusters may develop within the udder and biofilm structures, may facilitate bacterial adherence and colonization of the epithelium. In general all isolates could establish biofilms in $24 \mathrm{~h}$. Adhesion is a crucial early step for mammary gland infection but biofilm also may enable recurrent infections protecting bacterial cells from host defenses and the effects of antibiotics (Cucarella et al 2004).

\section{AUTOAGGREGATION}

The isolates showed a relative variable rate of autoaggregation values as can be seen in figure 1, Panel B. Iso- late 20090305 showed the highest aggregation rate with a relatively small variance, similarly to strain ATCC 25923. Mann-Whitney test showed that the autoaggregation rates of the 20 isolates could be grouped in at least 6 different classes (Group1: 20090305; Group 2: 20080607 , 20090109, 20080849, 20090108, 20080611; Group 3: 20090317; Group 4: 20090410; Group 5: 20080619, 20090409, 20080903, 20090307, 20080919; Group 6: 20090333, 20090323, 20080941, 20090431, 20090322, 20090436, 20090403). During the first stages of infection $S$. aureus produces hydrophobic surface proteins, particularly receptors for host components that allow the adherence to the mammary epithelium and milk fat globules and thus it disseminates in the gland also promoting intercellular aggregation (Kerro Dego et al 2002). Autoaggregation was seen in all isolates and also in different levels confirming bacterial adhesive capacity. However, no correlation could be established between bacterial autoaggregation and biofilm production.

\section{ANTIBIOTIC SUSCEPTIBILITY PATTERNS}

Only resistance against penicillin was observed, detected in $4 \mathrm{~S}$. aureus isolates (20\% excluding ATCC reference strains used as controls). All isolates were susceptible to the other agents or agent combinations; none of the isolates showed resistance to more than one antimicrobial agent.

These findings were similar to those reported by $\mathrm{Ru}-$ bin et al (2011). Although the number of isolates could be considered as limited, our data indicate that bacterial antibiotic resistance could be low in the area, probably due to appropriate therapeutic managements.

It can be concluded that all the isolates considered in this study expressed virulence factors that potentially enhance $S$. aureus ability to colonize and persist in the mammary gland and even on inert surfaces. The increase in the knowledge of $S$. aureus involved in subclinical mastitis may be useful to design effective measures to avoid the chronicity of infection and losses of productive animals.

\section{ACKNOWLEDGEMENTS}

This study was partially supported by the Comisión de Investigación y Desarrollo Científico (CIDEC) and the Posgraduate Program of the Facultad de Veterinaria, Universidad de la República, Uruguay.

\section{REFERENCES}

Bauer A, W Kirby, J Sherris, M Turck. 1966. Antibiotic susceptibility testing by a standardized single disk method. Am J Clin Pathol 45, 493-496.

Boerlin P, P Kuhnert, D Hüssy, M Schaellibaum. 2003. Methods for Identification of Staphylococcus aureus Isolates in Cases of Bovine Mastitis. J Clin Microbiol 41, 767-771.

Buzzola FR, LP Alvarez, LPN Tuchscherr, MS Barbagelata, 

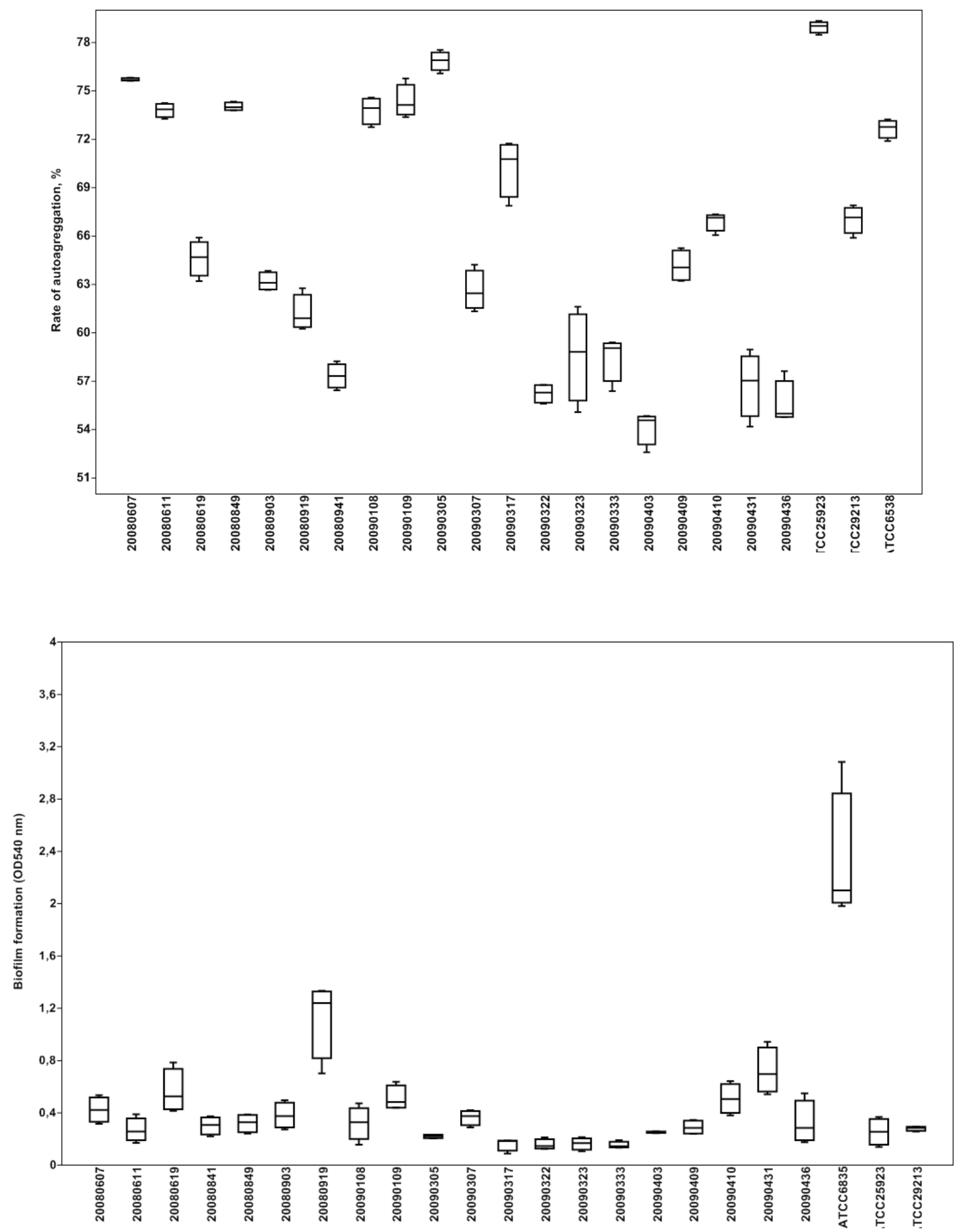

Figure 1. Panel A: Biofilm production of S. aureus isolates. Horizontal lines of each box correspond to the three quartiles of the replicates. Central horizontal lines correspond to the medians. Panel B: Autoaggregation rates of S. aureus isolates. Horizontal lines of each box correspond to the three quartiles of the replicates. Central horizontal lines correspond to the medians.

Panel A: Producción de biofilms por parte de las cepas de S. aureus. Las líneas horizontales de cada caja corresponden los tres cuartiles de las réplicas. Las líneas horizontales centrales corresponden a las medianas. Panel B: Autoagregación de las cepas de S. aureus. Las líneas horizontales de cada caja corresponden los tres cuartiles de las réplicas. Las líneas horizontales centrales corresponden a las medianas. 
SM Lattar, L Calvinho, DO Sordelli. 2007. Differential abilities of capsulated and noncapsulated Staphylococcus aureus isolates from diverse agr groups to invade mammary epithelial cells. Infect Immun 75, 886-891.

Cressier B, N Bissonnette. 2011. Assessment of an extraction protocol to detect the major mastitis-causing pathogens in bovine milk. J Dairy Sci 94, 2171-2184.

Cucarella C, M Tormo, C Úbeda, M Trotonda , M Monzón, C Peris, B Amorena, I Lasa, J R Penadés. 2004. Role of biofilm-associated protein Bap in the pathogenesis of bovine Staphylococcus aureus. Infect Immun 72, 2177-2185.

Delucchi L, M Fraga, K Perelmuter, E Cidade, P Zunino. 2008. Vaginal lactic acid bacteria in healthy and ill bitches and evaluation of in vitro probiotic activity of selected isolates. Can Vet J 49, 991-994.

Feitosa-Brito JR, GAV Caldeira, R da Silva-Verneque, MA Vasconcelos-Paiva e Brito. 1997. Sensibilidade e especificidade do California Mastitis Test como recurso diagnóstico da mastite subclínica em relação à contagem de células somáticas. Pesq Vet Bras 17, 49-53.

Gandara A, LC Mota, C Flores, HR Perez, CF Green, SG Gibbs. 2006. Isolation of Staphylococcus aureus and antibioticresistant Staphylococcus aureus from residential indoor bioaerosols. Environ Health Perspect 114, 1859-1864.

Gianneechini R, C Concha, R Rivero, I Delucci, J Moreno López. 2002. Occurrence of clinical and sub-clinical mastitis in dairy herds in the West littoral region in Uruguay. Acta Vet Scand 43, 221-230.

Hammer $\varnothing$, DAT Harper, PD Ryan. 2001. PAST Paleontological Statistics software package for education and data analysis. Palaentol Electron 4, 9.

Kateete D, CN Kimani, FA Katabazi, A Okeng, MS Okee, A Nanteza, ML Joloba, FC Najjuka. 2010. Identification of Staphylococcus aureus: DNase and Mannitol salt agar improve the efficiency of the tube coagulase test. Ann Clin Microbiol Antimicrob 9, 23.

Kerro Dego O, JE van Dijk, H Nederbragt. 2002. Factors involved in the early pathogenesis of bovine Staphylococcus aureus mastitis with emphasis on bacterial adhesion and invasion. A review. Vet $Q$ 24, 181-198.

Kumar R, BR Yadav, RS Singh. 2011. Antibiotic resistance and pathogenicity factors in Staphylococcus aureus isolated from mastitic Sahiwal cattle. J. Biosci 36, 175-188.

Larsen HD, FM Aarestrup, NE Jensen. 2002. Geographical variation in the presence of genes encoding superantigenic exotoxins and beta-hemolysin among Staphylococcus aureus isolated from bovine mastitis in Europe and USA. Vet Microbiol 85, 132-139.

Marrs CF, G Schoolnik, JM Koomey, J Hardy, J Rothbard, S Falkow. 1985. Cloning and sequencing of a Moraxella bovis pilin gene. J Bacteriol 163, 132-139.

Mathur T, S Singhal, S Khan, DJ Upadhyay, T Fatma, A Rattan. 2006. Detection of biofilm formation among the clinical isolates of Staphylococci: an evaluation of three different screening methods. Indian J Med Microbiol 24, 25-29.
National Committee for Clinical Laboratory Standards. 1997. Methods for antimicrobial susceptibility testing of anaerobic bacteria; approved standard. $4^{\text {th }}$ ed. Vol. 17. National Committee for Clinical Laboratory Standards, Wayne, $\mathrm{Pa}$, USA.

National Mastitis Council. 1981. Microbiological procedures for use in the diagnosis of Bovine Mastitis. $2^{\text {nd }}$ ed. National Mastitis Council Inc., Washington DC, USA.

Persson Y, A Nyman, U Grönlund-Andersson. 2011. Etiology and antimicrobial susceptibility of udder pathogens from cases of subclinical mastitis in dairy cows in Sweden. Acta Vet Scand 53-36.

Pfaller MA, D Davenport, M Bale, M Barrett, F Koontz, RM Massanari. 1988. Development of the quantitative microtest for slime production by coagulase negative staphylococci. Eur J Clin Microbiol 7, 30-33.

Plozza K, JJ Lievaart, G Potts, HW Barkema. 2011. Subclinical mastitis and associated risk factors on dairy farms in New South Wales. Aust Vet J 89, 41-46.

Quinn PJ, ME Carter, B Markey, GR Carter. 2004. Clinical Veterinary Microbiology. Mosby Publishing, London, UK.

Roberson JR, LK Fox, DD Hancock, TE Besser. 1992. Evaluation of methods for differentiation of coagulase-positive staphylococci. J Clin Microbiol 30, 3217-3219.

Rubin JE, KR Ball, M Chirino-Trejo. 2011. Antimicrobial susceptibility of Staphylococcus aureus and Staphylococcus pseudintermedius isolated from various animals. Can Vet $J$ 52, 153-157.

Rupp ME, GL Archer. 1992. Haemagglutination and adherence to plastic by Staphylococcus epidermidis. Infect Immun 60, 4322-4327.

Sibbald M, A Ziebandt, S Engelmann, M Hecker, A De Jong Harmsen, G Raangs, I Stokroos, J Arends, J Dubois, J van Dijl. 2006. Mapping the pathways to Staphylococcal pathogenesis by comparative secretomics. Microbiol Mol Biolog Rev 70, 755-788.

Sommerhäuser J, B Kloppert, W Wolter, M Zschöck, A Sobiraj, K Failing. 2003. The epidemiology of Staphylococcus aureus infections from subclinical mastitis in dairy cows during a control programme. Vet Microbiol 96, 91-102.

Tuchscherr LPN, FR Buzzola, LP Alvarez, RL Caccuri, JC Lee, DO Sordelli. 2005. Capsule-negative Staphylococcus aureus induces chronic experimental mastitis in mice. Infect Immun 73, 7932-7937.

Türkyilmaz S, O Kaya. 2006. Determination of some virulence factors in Staphylococcus spp. isolated from various clinical samples. Turk J Vet Anim Sci 30, 127-132.

Vasudevan P, M Kumar, M Nair, T Annamalai, K Venkitanarayanan. 2003. Phenotypic and genotypic characterization of bovine mastitis isolates of Staphylococcus aureus for biofilm formation. Vet Microbiol 92, 179-185.

Zecconi A, L Cesaris, E Liandris, V Daprà, R Piccinini. 2006. Role of several Staphylococcus aureus virulence factors on the inflammatory response in bovine mammary gland. Microb Pathog 40, 177-183. 